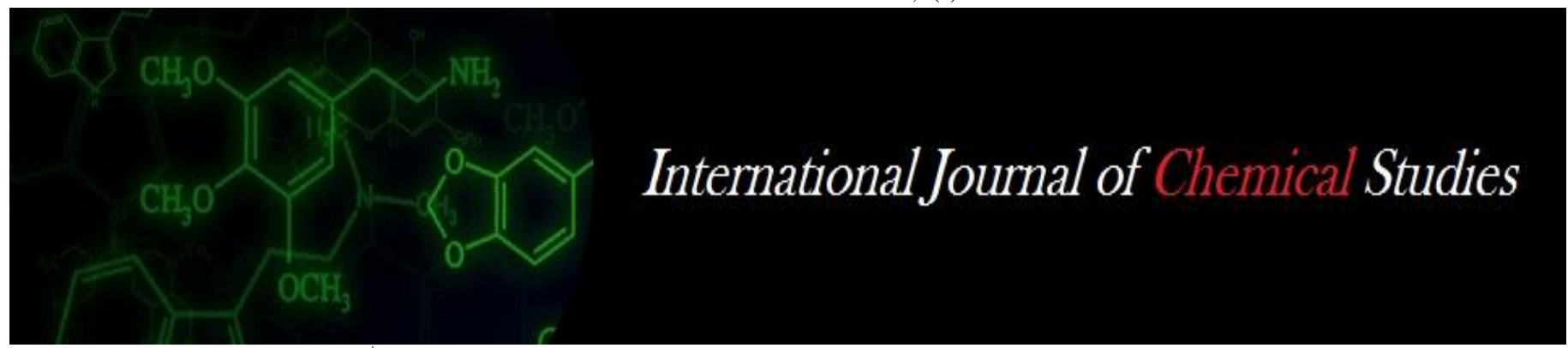

P-ISSN: 2349-8528

E-ISSN: 2321-4902

IJCS 2020; 8(1): 2115-2119

(C) 2020 IJCS

Received: 07-11-2019

Accepted: 09-12-2019

\section{MS Gawankar}

College of Horticulture, Mulde,

Dist. Sindhudurg, Maharashtra, India

\section{SV Juvekar}

M. Sc. (Hort) Students.

Department of Horticulture,

College of Horticulture, Dapoli,

Maharashtra, India

\section{Rajput}

M. Sc. (Hort) Students.

Department of Horticulture,

College of Horticulture, Dapoli,

Maharashtra, India

BR Salvi

Head, Department of

Horticulture, College of

Agriculture, Dapoli,

Maharashtra, India

Corresponding Author:

MS Gawankar

College of Horticulture, Mulde,

Dist. Sindhudurg, Maharashtra,

India

\section{Economics of growing kokum (Garcinia indica Choisy) seedling on different potting media}

\author{
MS Gawankar, SV Juvekar, DC Rajput and BR Salvi
}

DOI: https://doi.org/10.22271/chemi.2020.v8.i1af.8580

\section{Abstract}

Kokum (Garcinia indica Choisy) is commonly known as Kokum butter tree and underexploited tree spices mostly found in Konkan region of Maharashtra, Goa, Karnataka, Kerala and Surat district of Gujarat on the West Coast of India (Haldankar et al., 2012 and Braganza et al., 2012) ${ }^{[6,2]}$. The seeds (Kernels) are rich source of oil known as kokum butter, which is in solid form at room temperature Availability of strong and vigorous seedling as a rootstock plays vital role in the success of nursery programme. With a view to hasten the growth of seedling in order to get strong and vigorous seedling as rootstock at early stage of growth an experiment was undertaken at College of Horticulture, Dapoli, Dist. Ratnagiri 415712 (M.S.) during the year 2018 to find out most effective potting media for seedling growth of Kokum.

The experiment was conducted in Randomized Block Design with six treatments and four replications. The treatment comprises $\mathrm{T}_{1}$ : Soil + FYM (3:1) with 1" Cocopeat at top, T2: Soil + Vermicompost (3:1) with 1" Cocopeat at top, T3: Soil + FYM + Vermicompost $(2: 1: 1)$ with 1" Cocopeat at top, T4: Soil + FYM + Rice husk (1:1:1) with 1'Cocopeat at top, T5: Soil + FYM + Vermicompost + Cocopeat (1:1:1:1) and $\mathrm{T}_{6}$ : Soil + FYM (1:1). Results revealed that treatment $\mathrm{T}_{6}$ i. e. Soil + FYM at 1:1 proportion recorded maximum seedling height $(48.60 \mathrm{~cm})$, more number of leaves $(39.83)$, highest leaf length $(20.11 \mathrm{~cm})$, leaf width $(1.93 \mathrm{~cm})$, leaf area $\left(40.61 \mathrm{~cm}^{2}\right)$ and the highest AGR $(0.094 \mathrm{~cm} /$ day $)$ and RGR (0.0024 $\mathrm{cm} / \mathrm{cm} /$ day) at 360 days. Similarly, media containing Soil + FYM at 1:1 proportion recorded highest seedling survival percentage $(97.50 \%)$ and highest percentage of graftable seedlings $(83.25 \%)$ at 360 $\mathrm{DAB}$ and resulted in generating higher gross income (Rs. 3900), maximum net returns (Rs. 467.61) with highest $\mathrm{B}$ : $\mathrm{C}$ ratio (1.13) and seedling grown on this media were light in weight and easy to transport.

Keywords: Media, growth, survival and graftable seedlings

\section{Introduction}

Kokum (Garcinia indica choisy) is underexploited dioecious tree condiment belongs to family Guttiferae. It is commonly known as Kokum butter tree in English and vernacular names are kokum, ratamba, birand, amsol (Braganza et al., 2012) ${ }^{[2]}$. Kokum is commonly known as Kokum butter tree in English and other vernacular names are kokum, ratamba, birand, amsol (Konkani and Marathi) brindon (Portuguese in Goa), murugalu (Kannada) and punarpuli (Malayalam) (Braganza et al., 2012) ${ }^{[2]}$.

Kokum has got multifarious uses and therefore, finds an inevitable place in the lifestyle of local population. The fruit juice is used for preparation of syrup, squash, RTS, agal (salted juice) etc. The dried rind is used as a souring agent in Goan cuisine. The seeds are rich source of oil known as kokum butter, which is in solid form at room temperature. It is nutritive and used for smoothening, softening etc. It is also used for cosmetic, confectionary and culinary purposes.

As the growth of kokum seedling at nursery establishment is very slow which needs to hasten to get vigorous rootstock for grafting at early stage of growth. Soil + FYM (3:1) is a basic media used for nursery production. However, its requirement in nursery programme is very huge and becoming scare with time. Different growing media other than soil like Cocopeat, Rice husk, FYM, Vermicompost etc. are light in weight and also have good porous structure which can be used as component along with soil. Very little work on economic importance of different media on growth of underexploited fruit trees has been done with this view; present investigation to find out most economic potting media for seedling growth of Kokum was carried out. 


\section{Material \& Methods}

The experiment was conducted at College of Horticulture, under Dr. Balasheb Sawant Konkon Krishi Vidyapeeth, Dapoli, Dist. Ratnagiri 415712 (MS.) during the year 2018 as a part of M. Sc (Hort.) degree programme. The experiment was laid out in Randomized Block Design with six treatments namely $\mathrm{T}_{1}$ : Soil + FYM (3:1) with 1 " Cocopeat at top, $\mathrm{T}_{2}$ : Soil + Vermicompost $(3: 1)$ with 1" Cocopeat at top, $\mathrm{T}_{3}$ : Soil + FYM + Vermicompost $(2: 1: 1)$ with 1 " Cocopeat at top, $\mathrm{T}_{4}$ : Soil + FYM + Rice husk (1:1:1) with 1" Cocopeat at top, $\mathrm{T}_{5}$ : Soil + FYM + Vermicompost + Cocopeat $(1: 1: 1: 1)$ and $\mathrm{T}_{6}$ : Soil + FYM (1:1) and treatments were replicated four times. Randomly selected six-month-old kokum seedlings uniform in growth grown in polybags of size $6 " \times 8^{\prime \prime}$ were transferred in polythene bags of $9 "$ " $\mathrm{x} 11^{\prime \prime}$ size and used for the experimental purpose. A group of 100 seedlings was formed a unit. Average leaf length $(\mathrm{cm})$, average leaf width $(\mathrm{cm})$ and leaf area $\left(\mathrm{cm}^{2}\right)$ were measured with the help of Portable leaf area meter (Licor, company. USA.). Absolute growth rate (cm/day) AGR for increase in plant height was calculated by using formula given by Radford (1967) ${ }^{[13]}$ and expressed as height in $\mathrm{cm} /$ day.
Where, $\mathrm{H}_{2}$ and $\mathrm{H}_{1}$ represent height per plant and $\mathrm{t}_{2}$ and $\mathrm{t}_{1}$ time intervals between two observations, respectively.

Relative growth rate $(\mathrm{cm} / \mathrm{cm} /$ day $)$ is the rate of increase in height $(\mathrm{cm})$ per time and expressed as $\mathrm{cm} / \mathrm{cm} /$ day. RGR was calculated by the using formula given by Briggs et al. (1920) [3]

$$
\mathrm{RGR}=\frac{\left(\log _{\mathrm{e}} \mathrm{H}_{2}-\log _{\mathrm{e}} \mathrm{H}_{1}\right)}{\left(\mathrm{t}_{2} \mathrm{t}_{1}\right)}
$$

Where, $\mathrm{H}_{2}$ and $\mathrm{H}_{1}$ represent the plant height per plant at $\mathrm{t}_{2}$ and $\mathrm{t}_{1}$ times, respectively. Statistical analysis of the data was carried out by following the standard method of analysis of variance as given by Panse and Sukhatme (1985) ${ }^{[10]}$. Graphs and plates have been used to project the important results.

\section{Result \& Discussion}

Data pertaining to height of seedling, number of leaves, number of shoots and leaf characters are presented in Table 1 and depicted with Figure 1.

$\operatorname{AGR}=\frac{\left(\mathrm{H}_{2}-\mathrm{H}_{1}\right)}{\left(\mathrm{t}_{2}-\mathrm{t}_{1}\right)}$

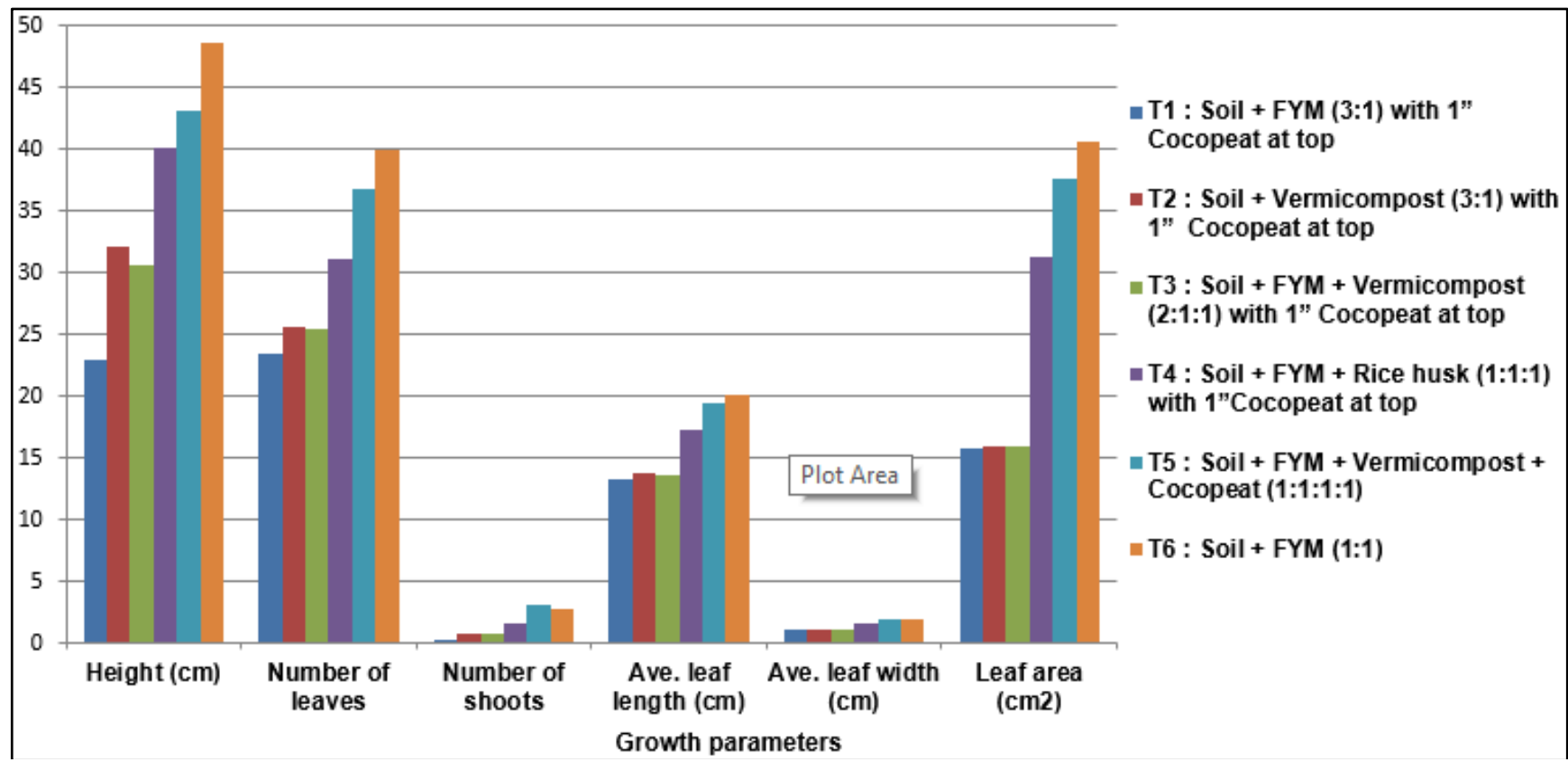

Fig 1: Performance of kokum seedlings on different potting media

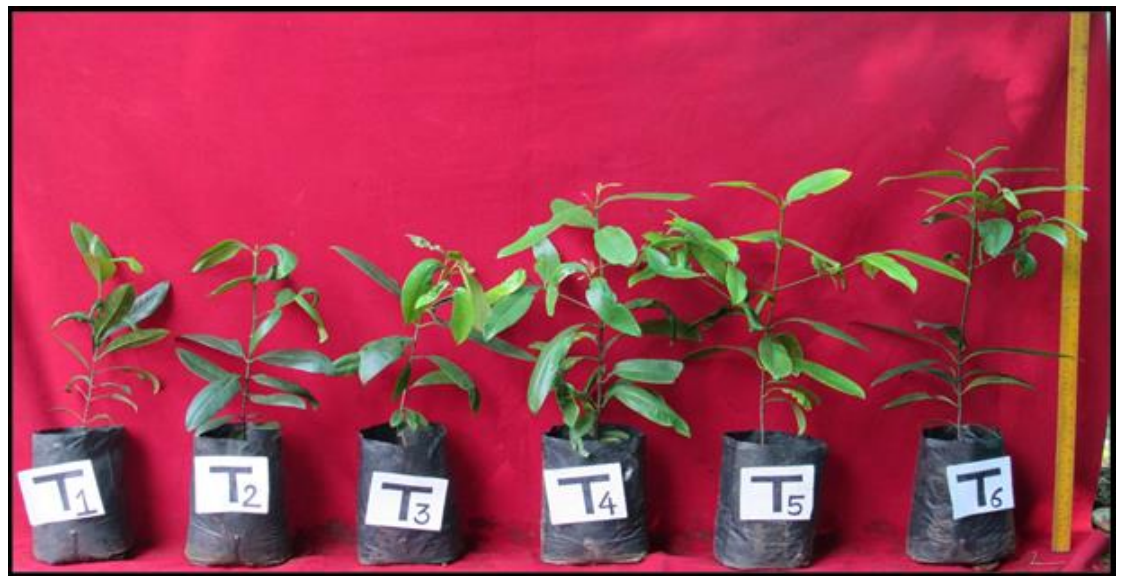

Plate 1: Performance of kokum seedlings grown on different growing media at 360 days after bagging in 9" x 11" size polybag 
Table1: Effect of different growing media on growth of kokum seedlings at 360 days after bagging (DAB)

\begin{tabular}{|c|c|c|c|c|c|c|}
\hline Treatments & $\begin{array}{c}\text { Height } \\
(\mathrm{cm})\end{array}$ & \begin{tabular}{|c} 
Number of \\
leaves
\end{tabular} & \begin{tabular}{|l|} 
Number \\
of shoots
\end{tabular} & $\begin{array}{c}\text { Ave. leaf } \\
\text { length }(\mathrm{cm})\end{array}$ & $\begin{array}{c}\text { Ave. leaf } \\
\text { width }(\mathrm{cm})\end{array}$ & $\begin{array}{c}\text { Leaf area } \\
\left(\mathrm{cm}^{2}\right)\end{array}$ \\
\hline $\mathrm{T}_{1}$ : Soil + FYM (3:1) with 1" Cocopeat at top & 22.95 & 23.40 & 0.18 & 13.22 & 1.09 & 15.73 \\
\hline $\mathrm{T}_{2}$ : Soil + Vermicompost (3:1) with 1" Cocopeat at top & 31.98 & 25.58 & 0.70 & 13.65 & 1.11 & 15.83 \\
\hline T3: Soil + FYM + Vermicompost (2:1:1) with 1" Cocopeat at top & 30.56 & 25.38 & 0.65 & 13.53 & 1.13 & 15.81 \\
\hline T4: Soil + FYM + Rice husk (1:1:1) with 1"Cocopeat at top & 40.03 & 31.03 & 1.60 & 17.25 & 1.61 & 31.27 \\
\hline $\mathrm{T}_{5}$ : Soil + FYM + Vermicompost + Cocopeat $(1: 1: 1: 1)$ & 43.13 & 36.73 & 2.98 & 19.38 & 1.81 & 37.56 \\
\hline T6: Soil + FYM (1:1) & 48.60 & 39.83 & 2.65 & 20.11 & 1.93 & 40.61 \\
\hline SEm \pm & 1.24 & 1.36 & 0.25 & 0.81 & 0.08 & 2.55 \\
\hline CD@ @ $5 \%$ & 3.73 & 4.10 & 0.77 & 2.44 & 0.23 & 7.69 \\
\hline
\end{tabular}

\section{Effect of growing media on seedling height}

Data presented in Table 1 revealed that at 360 DAB maximum height $(48.60 \mathrm{~cm})$ was recorded in $\mathrm{T}_{6}($ Soil $+\mathrm{FYM}$ $1: 1)$ and was superior over the rest of the treatments. Treatment $\mathrm{T}_{4}$ (40.03) was at par with $\mathrm{T}_{5}$ (43.13) (Soil + FYM + Vermicompost + Cocopeat 1:1:1:1). The minimum height $(22.95 \mathrm{~cm})$ was observed in $\mathrm{T}_{1}$ (Soil + FYM (3:1) with 1" Cocopeat at top). It was observed that treatment $\mathrm{T}_{6}$ (Soil + FYM 1:1) was found to be superior for height of kokum seedling. This may be due to the role of FYM in increasing aeration and water holding capacity of soil, availability of essential nutrients for plant growth and also improve soil physical, chemical and biological properties (Ramteke et al., 2016) ${ }^{[14]}$. Similar findings were reported by Parasana et al., (2013) for mango in growing media containing Soil + Sand + FYM (2: 1: 1), Panchal et al., (2014) ${ }^{[8]}$ for khirni seedling in Soil + Cocopeat + FYM $(1: 1: 1)$.

\section{Effect of growing media on number of leaves}

At 360 DAB the maximum number of leaves (39.83) was recorded in treatment $\mathrm{T}_{6}$ (Soil + FYM 1:1) which was at par with $\mathrm{T}_{5}$ (36.73). The minimum number of leaves (23.40) were recorded in treatment $\mathrm{T}_{1}$ (Soil + FYM (3:1) with 1" Cocopeat at top) which was at par with $\mathrm{T}_{3}(25.38)$ and $\mathrm{T}_{2}$ (25.58). The results revealed that treatment $\mathrm{T}_{6}$ (Soil + FYM 1:1) found to be superior for increasing number of leaves of kokum seedling. The possible reason was nutritional contribution of the growing media. Soil mixtures with organic substrates such as farm yard manure enhanced the production of leaves. Similar results were reported by Parasana et al., (2013) in mango for growing media containing Soil + Sand + FYM (2: 1: 1), Gholap and Polara (2015 a) ${ }^{[5]}$ for mango rootstock in Soil + FYM + Leaf mould (1:1:1) media, Panchal et al., $(2014)^{[8]}$ for khirni seedling in Soil + Cocopeat + FYM $(1: 1: 1)$ and Khot (2017) ${ }^{[7]}$ for Bullock's heart in Soil + FYM $(2: 1)$ media.

\section{Effect of growing media on number of shoots}

At 360 DAB the highest number of shoots (2.98) was recorded in treatment $\mathrm{T}_{5}$ (Soil + FYM + Vermicompost + Cocopeat 1:1:1:1) followed by $\mathrm{T}_{6}(2.65)$ and both were at par with each other. The minimum number of shoots $(0.18)$ was observed in treatment $\mathrm{T}_{1}$ (Soil + FYM (3:1) with 1" Cocopeat at top) which was at par with $\mathrm{T}_{3}(0.65)$ and $\mathrm{T}_{2}(0.70)$.

The results showed that the treatment $\mathrm{T}_{5}$ (Soil + FYM + Vermicompost + Cocopeat 1:1:1:1) found superior for increasing number of branches of kokum seedling. Improved aeration of media, water holding capacity, cation exchange capacity and increased nutrient status of media which might have increased the growth of plant by producing more number of shoots. The results are in accordance with the findings obtained by Panchal et al., (2014) ${ }^{[8]}$ for khirni seedlings in Soil + Cocopeat + FYM (1:1:1) media, Qayom (2011) for mango seedlings in Soil + Sand + Compost + Coir pith $(2: 1: 1: 1)$ media.

\section{Effect of growing media on leaf length}

At $360 \mathrm{DAB}$ the treatment $\mathrm{T}_{6}$ recorded the highest leaf length $(20.11 \mathrm{~cm})$ in media Soil + FYM 1:1) and was at par with $\mathrm{T}_{5}$ $(19.38 \mathrm{~cm})$. The lowest leaf length $(13.22 \mathrm{~cm})$ was recorded in treatment $\mathrm{T}_{1}$ (Soil + FYM (3:1) with 1 " Cocopeat at top) however it was at par with $\mathrm{T}_{3}(13.53 \mathrm{~cm})$ and $\mathrm{T}_{2}(13.65 \mathrm{~cm})$. Thus, the present investigation showed that the leaf length was influenced by media. It was maximum in treatment $\mathrm{T}_{6}$ (Soil + FYM 1:1). The results are in accordance with the findings of Gawankar (2019) ${ }^{[4]}$ in jackfruit.

\section{Effect of growing media on leaf width}

At 360 DAB the highest average leaf width $(1.93 \mathrm{~cm})$ was recorded in treatment $\mathrm{T}_{6}$ (Soil + FYM 1:1) which was at par with $\mathrm{T}_{5}(1.81 \mathrm{~cm})$. The lowest average leaf width $(1.09 \mathrm{~cm})$ was observed in treatment $\mathrm{T}_{1}$ (Soil + FYM (3:1) with 1" Cocopeat at top) which was at par with $\mathrm{T}_{2}(1.11 \mathrm{~cm})$ and $\mathrm{T}_{3}$ $(1.61 \mathrm{~cm})$. Thus, the study revealed that treatment $\mathrm{T}_{6}$ (Soil + FYM 1:1) found to be superior for average leaf width of kokum seedling.

\section{Effect of growing media on leaf area}

At $360 \mathrm{DAB}$ the highest leaf area $\left(40.61 \mathrm{~cm}^{2}\right)$ was recorded in treatment $\mathrm{T}_{6}$ (Soil + FYM 1:1) which was at par with $\mathrm{T}_{5}$ $\left(37.56 \mathrm{~cm}^{2}\right)$. While the lowest leaf area $\left(15.73 \mathrm{~cm}^{2}\right)$ was observed in treatment $\mathrm{T}_{1}$ (Soil + FYM (3:1) with 1" Cocopeat at top) which was at par with $\mathrm{T}_{3}\left(15.81 \mathrm{~cm}^{2}\right)$ and $\mathrm{T}_{2}(15.83$ $\mathrm{cm}^{2}$ ).

The study revealed that the leaf area of kokum was influenced by media and was maximum in treatment $\mathrm{T}_{6}$ (Soil + FYM $1: 1)$. The availability of nutrients in growing substrate greatly affects the size of leaves. The dimension of leaf namely leaf length, leaf width and leaf area are deciding the opportunity to capture solar radiation which is the main determinant of photosynthesis and overall growth of seedling.

In current investigation maximum leaf length, leaf width and leaf area were noticed under Soil + FYM 1:1 proportion. This could be due to properties of media namely $\mathrm{pH}$ value, EC value and NPK content and water holding capacity favorable for emergence and expansion of leaves. Peter-Onoh et al., (2014) ${ }^{[11]}$ have also reported that the standard nursery soil is appropriate growth media for stimulation of emergence and expansion of leaves in African nutmeg. Similar findings were reported by Bhardwaj (2014) ${ }^{[1]}$ in papaya.

\section{Effect of growing media on absolute growth rate (AGR)}

Data pertaining to the effect of different growing media on absolute growth rate $(\mathrm{cm} /$ day) are presented in Table 2 . At 0 $180 \mathrm{DAB}$ the highest AGR (0.094 $\mathrm{cm} /$ day) recorded in treatment $\mathrm{T}_{6}$ and the lowest AGR $(0.045 \mathrm{~cm} /$ day $)$ was 
observed in $\mathrm{T}_{1}$ (Soil + FYM (3:1) with 1" Cocopeat at top). At 180-360 DAB the highest AGR $(0.140 \mathrm{~cm} /$ day $)$ was observed in treatment $\mathrm{T}_{6}($ Soil + FYM 1:1) and lowest AGR $(0.052$ cm/day) was in $T_{1}$ (Soil + FYM (3:1) with 1" Cocopeat at top).

Table 2: Effect of different growing media on absolute growth rate $(\mathrm{cm} / \mathrm{cm} /$ day) and relative growth rate $(\mathrm{cm} / \mathrm{cm} /$ day) of kokum seedling

\begin{tabular}{|c|c|c|c|}
\hline \multirow{2}{*}{ Treatments } & \multicolumn{2}{|c|}{ Absolute growth rate $(\mathrm{cm} /$ day $)$} & \multirow{2}{*}{\begin{tabular}{|c} 
Relative growth rate $(\mathrm{cm} / \mathrm{cm} /$ day $)$ \\
$0-360$ DAB
\end{tabular}} \\
\hline & 0-180 DAB & 180-360 DAB & \\
\hline $\mathrm{T}_{1}$ - Soil + FYM (3:1) with 1" Cocopeat at top & 0.045 & 0.052 & 0.0018 \\
\hline $\mathrm{T}_{2}-$ Soil + Vermicompost (3:1) with 1" Cocopeat at top & 0.057 & 0.089 & 0.0021 \\
\hline $\mathrm{T}_{3}-$ Soil + FYM + Vermicompost (2:1:1) with 1" Cocopeat at top & 0.056 & 0.080 & 0.0020 \\
\hline $\mathrm{T}_{4}$ - Soil + FYM + Rice husk (1:1:1) with 1" Cocopeat at top & 0.078 & 0.111 & 0.0023 \\
\hline $\mathrm{T}_{5}-$ Soil + FYM + Vermicompost + Cocopeat $(1: 1: 1: 1)$ & 0.084 & 0.120 & 0.0023 \\
\hline $\mathrm{T}_{6}-$ Soil + FYM $(1: 1)$ & 0.093 & 0.140 & 0.0024 \\
\hline Mean & 0.069 & 0.099 & 0.0021 \\
\hline
\end{tabular}

In current investigation, Soil + FYM 1:1 has maximum AGR magnitude at different growth stages indicating media with high proportion of soil is necessary for better absolute growth rate of seedling. Ramteke et al., (2016) ${ }^{[14]}$ who observed maximum AGR of papaya seedling in media having Soil + Sand + Cocopeat and vermicompost in 1:1:1:1 proportion.

\section{Effect of growing media on relative growth rate (AGR)}

RGR is an index of efficiency of the plant to grow in contest of the photosynthesis of the crop per unit area. It measures the efficiency of the plant to grow per unit area per unit time. It is the growth rate relative to previous size. It is also called as exponential growth rate which is a quantification of speed of plant growth.

Data regarding effect of different growing media on relative growth rate $(\mathrm{cm} / \mathrm{cm} /$ day) are presented in the table (Table 2). At 360 DAB the highest RGR $(0.0024 \mathrm{~cm} / \mathrm{cm} /$ day $)$ was observed in treatment $\mathrm{T}_{6}$ (Soil + FYM 1:1) and the lowest RGR $\left(0.0018 \mathrm{~cm} / \mathrm{cm} /\right.$ day) was observed in $\mathrm{T}_{1}$ (Soil + FYM (3:1) with 1" Cocopeat at top).

Study revealed that the treatment $\mathrm{T}_{6}$ (Soil + FYM 1:1) recorded the maximum RGR of kokum seedling. This may be due to the fact that FYM would have increased aeration and water holding capacity in soil, availability of essential nutrients for plant growth and conversions of unavailable nutrients to available forms through microbial activity. Similar results were reported by Ramteke et al., (2016) ${ }^{[14]}$ for papaya seedling in soil + FYM (1:1) media and Panchal et al., (2014) ${ }^{[8]}$ in khirni.

\section{Effect of growing media on seedling survival percentage}

Data presented in Table 3 indicated that the highest survival of seedlings $(97.50 \%)$ was also recorded in treatment $\mathrm{T}_{6}$ (Soil + FYM 1:1) which was at par with $\mathrm{T}_{4}(97.00 \%)$ and $\mathrm{T}_{5}$ $(95.00 \%)$. Significantly the lowest survival of seedling $(91.50 \%)$ was recorded in treatment $\mathrm{T}_{1}$ (Soil + FYM (3:1) with 1" Cocopeat at top) and was at par with treatment $\mathrm{T}_{2}$ $(93.25 \%)$ and $\mathrm{T}_{3}(93.50 \%)$. In present investigation treatment $\mathrm{T}_{6}$ i.e. media having Soil $+\mathrm{FYM}$ at 1:1 reported maximum survival percentage of kokum seedling indicating effectiveness of FYM in the media which was also been reported by Qyom (2011) and Gholap and Polara (2015) ${ }^{[5]}$ in mango.

Table 3: Survival percentage (\%), percentage of graftable size seedlings and economics of growing kokum seedlings in different potting media (100 seedlings)

\begin{tabular}{|c|c|c|c|c|c|c|c|}
\hline Treatments & $\begin{array}{c}\text { Survival } \\
\text { percentage } \\
(\%)\end{array}$ & \begin{tabular}{|c|}
$\begin{array}{c}\text { Percentage of } \\
\text { graftable } \\
\text { seedlings }\end{array}$ \\
\end{tabular} & $\begin{array}{c}\text { Gross } \\
\text { income } \\
\text { Rs. }\end{array}$ & $\begin{array}{l}\text { Total } \\
\text { cost } \\
\text { Rs. } \\
\end{array}$ & $\begin{array}{c}\text { Net returns } \\
\text { Rs. }\end{array}$ & $\begin{array}{l}\text { Net } \\
\text { B:C } \\
\text { ratio }\end{array}$ & \begin{tabular}{|c} 
Weight \\
of bag \\
(kg)
\end{tabular} \\
\hline $\mathrm{T}_{1:}$ Soil + FYM (3:1) with 1" Cocopeat at top & $91.50(73.41)$ & $56.75(49.06)$ & 3660 & 3765.31 & (-) 105.32 & 0.97 & 2.500 \\
\hline $\mathrm{T}_{2}$ : Soil + Vermicompost (3:1) with 1" Cocopeat at top & $93.25(75.08)$ & $75.00(60.11)$ & 3730 & 4565.77 & $(-) 835.78$ & 0.81 & 2.700 \\
\hline $\mathrm{T}_{3:}$ Soil + FYM + Vermicompost (2:1:1) with 1" Cocopeat at top & $93.50(75.34)$ & $81.00(64.31)$ & 3740 & 4457.44 & $(-) 711.45$ & 0.84 & 2.800 \\
\hline T4: Soil + FYM + Rice husk (1:1:1) with 1" Cocopeat at top & $97.00(80.35)$ & $89.00(70.83)$ & 3880 & 3639.57 & 240.41 & 1.06 & 1.900 \\
\hline T5: Soil + FYM + Vermicompost + Cocopeat $(1: 1: 1: 1)$ & $95.00(77.19)$ & $87.75(69.96)$ & 3800 & 4076.90 & $(-) 276.91$ & 0.93 & 2.000 \\
\hline $\mathrm{T}_{6}$ : Soil + FYM (1:1) & $97.50(82.45)$ & $90.00(76.61)$ & 3900 & 3432.37 & 467.61 & 1.13 & 1.700 \\
\hline SEm \pm & 1.24 & 3.71 & & & & & \\
\hline CD@ @ & 3.72 & 11.20 & & & & & \\
\hline
\end{tabular}

\section{Effect of different growing media on graftable size seedlings}

Obtaining healthy and vigorous seedling which is further utilized for grafting purpose is the important aspect for any nursery programme. The data pertaining to percentage of graftable size seedlings as influenced by different media presented in Table 3 revealed that significantly the highest percentage of graftable seedlings was obtained in the treatment $\mathrm{T}_{6}(83.25 \%)$ i.e. in media Soil + FYM at 1:1 proportion and was at par with $\mathrm{T}_{4}(81.75 \%), \mathrm{T}_{2}$ and $\mathrm{T}_{3}$ (71.75\%) and $\mathrm{T}_{5}(71.00 \%)$. Significantly lowest percentage of graftable seedlings was obtained in $\mathrm{T}_{1}(45.75 \%)$ where Soil + FYM at 3:1 proportion with 1" Cocopeat at top was the potting media. Study revealed that kokum seedlings rose in Soil + FYM at 1:1 proportion produced 83.25 percent graftable seedlings at earliest of 360 days after bagging. Thus, media having Soil + FYM at 1:1 proportion found effective in enhancing growth of seedling for obtaining graftable size seedlings. This may be due to the media containing Soil + FYM might have accredited nutritional status in the media which enhanced photosynthetic activity resulted in more plant stored material, thereby exhibited favourable effect on seedling growth (Gholap and Polara 2015) ${ }^{[5]}$. 


\section{Cost of production of Kokum seedlings on different potting media}

The data on gross income, total cost, net returns, benefit to cost ratio (B: C) and weight of seedling at a time of sale as influenced by different growing media are presented in Table 3.

Cost of producing 100 seedlings on different media indicated that total cost on production of seedling was the highest in treatment $\mathrm{T}_{2}$ (Rs. 4565.77) which is due to more proportion and expenditure on soil. Gross income generated was the highest in treatment $\mathrm{T}_{6}$ (Rs. 3900) and minimum in treatment $\mathrm{T}_{1}$ (Rs.3660). Net returns (Rs. 467.61) and B: C ratio (1.13) was the highest in treatment $\mathrm{T}_{6}$. This may be due to highest survival of seedling found in this treatment.

Thus, treatment $\mathrm{T}_{6}$ (Soil + FYM (1:1)) was found superior and resulted in generating higher gross income (Rs. 3900), maximum net returns (Rs. 467.61) with highest B: C ratio (1.13). The weight of bag was also less in this treatment $(1.700 \mathrm{~kg} / \mathrm{bag})$.

\section{Conclusion}

In present study growing media having Soil + FYM at 1:1 proportion was found better for increasing seedling height, number of leaves, leaf area, survival percentage of seedling after transferring in bigger size polybag and getting more percentage of graftable seedlings at early stage of growth. Thus, it is concluded that use of Soil + FYM of 1:1 proportion is the best medium for raising seedlings.

\section{References}

1. Bhardwaj RL. Effect of growing media on seed germination and seedling growth of papaya cv. 'Red lady'. African Journal of Plant Science. 2014; 8(4):178184.

2. Braganza Miguel, Ajit Shirodkar, Jayarama Bhat D, Krishnan S. Resource Book on Kokum, Western Ghats Kokum Foundation, Panaji - Goa. India, 2012.

3. Briggs GE, Kidd F, West C. A quantitative analysis of crop growth. Ann. Appl. Biol. 1920; 7:202-203.

4. Gawankar MS. Studies on seed storage methods for seed viability and effect of growing media on softwood grafting in jackfruit (Atrocarpus heterophyllus Lam.) A Ph.D. (Agri.) thesis submitted to Dr. B. S. Konkan Krishi Vidyapeeth, Dapoli, 2019.

5. Gholap SS, Polara ND. Effect of growing media and storage of stone on the success and survival of soft wood grafting in mango (Manifera indica L). The American journal of science and medical research. 2015; 1(1):23776196.

6. Haldankar PM, Pawar CD, Kshirsagar PJ, Kulkarni MM. Present Status and future thrust areas in production technology of Kokum (Garcinia indica Choisy). Resource Book on Kokum, Western Ghats Kokum Foundation, Panaji - Goa. India, 2012.

7. Khot AA. Effect of different potting media on success and growth of Bullock's Heart (Annona reticulata L.). M.Sc. (Agri.) thesis submitted to Dr. B. S. Konkan Krishi Vidyapeeth, Dapoli, Maharashtra, 2017.

8. Panchal GP, Parasana JS, Patel SR, Patel MV. Effect of different growing media and levels of Iba on growth and development of Khirni (Manilkara hexandra Roxb) seedlings Cv. Local. Global Journal of Bioscience and Biotechnology. 2014; 3(4):379-383.

9. Parasana JS, Ray NR, Satodiya BN, Patel KA, Panchal, GP. Effect of mixture of growing media on germination and seedlings growth of different mango (Mangifera indica L.) cultivars under net house conditions, Asian J. Hort. 2012; 7(2):409-411.

10. Panse VG, Sukhatme PV. Statistical method for agricultural workers. Indian Council of agricultural research New Delhi, fourth edition, 1985.

11. Peter-Onoh CA, Obiefuna JC, Ngwuta AA, Onoh PA, Ibeawuchi II, Ekwugha EU. et al Efficacy of five different growth media in seedling emergence and juvenile phenology of Monodora myristica (African nutmeg, Ehuru) in the nursery. Journal of Agricultural and Veterinary Science. 2014; 7(5):60-63.

12. Qayom A. Studies on the effect of media composition on seed germination, growth and its effect on grafting in mango (Mangifera indica L.). M.Sc. (Horti.) thesis submitted to the University of Agricultural Sciences, Bangalore, 2011.

13. Radford PJ. Growth analysis formulae, their use and abuse. Crop Sci. 1967; 7:171-175.

14. Ramteke V, Paithankar DH, Baghel MM, Kurrey VK. Impact of $\mathrm{ga}_{3}$ and propagation media on growth rate and leaf chlorophyll content of papaya seedlings. Research Journal of Agricultural Sciences. 2016; 7(1):169-171. 